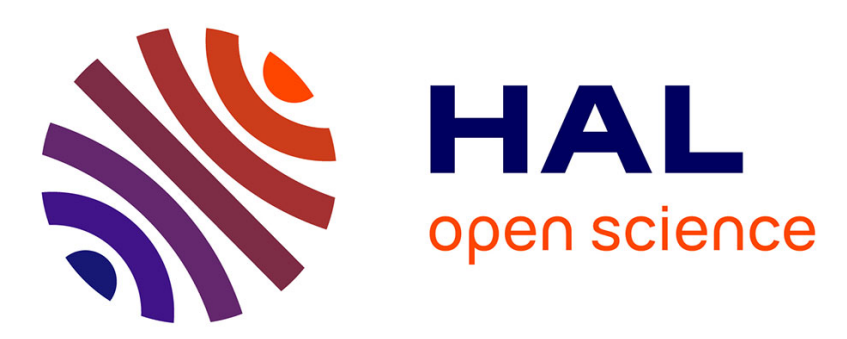

\title{
CHARACTERISTIC S OF THIN, MULTI-LAYERED FERROELECTRIC CERAMICS OBTAINED BY PROJECTION WITH A PLASMA-TORCH OR BY FRITTING
}

\author{
H. Kleimann, Mme Paletto, Murielle Richard
}

\section{To cite this version:}

H. Kleimann, Mme Paletto, Murielle Richard. CHARACTERISTIC S OF THIN, MULTILAYERED FERROELECTRIC CERAMICS OBTAINED BY PROJECTION WITH A PLASMATORCH OR BY FRITTING. Journal de Physique Colloques, 1972, 33 (C2), pp.C2-270-C2-271. 10.1051/jphyscol:1972295 . jpa-00215031

\section{HAL Id: jpa-00215031 https://hal.science/jpa-00215031}

Submitted on 1 Jan 1972

HAL is a multi-disciplinary open access archive for the deposit and dissemination of scientific research documents, whether they are published or not. The documents may come from teaching and research institutions in France or abroad, or from public or private research centers.
L'archive ouverte pluridisciplinaire HAL, est destinée au dépôt et à la diffusion de documents scientifiques de niveau recherche, publiés ou non, émanant des établissements d'enseignement et de recherche français ou étrangers, des laboratoires publics ou privés. 
- Au point de Curie, on n'observe plus la variation anormale de la constante diélectrique.

Une analyse structurale aux rayons $X$ permet de mettre en évidence que, après projection, le matériau présente une structure pseudo-cubique (Fig. 1) à la température ambiante. Un recuit de 4 heures à $1300{ }^{\circ} \mathrm{C}$ permet cependant de régénérer cette structure (Fig. 2) et ses caractéristiques ferroélectriques.

Les remarques précédentes rendent cependant délicate la technologie de fabrication des céramiques ferroélectriques par projection. Aussi avons-nous utilisé la technique du frittage pour réaliser une céramique ferroélectrique multicouche de composés binaires du type $\mathrm{Ba}_{x} \mathrm{Sr}_{1-x} \mathrm{TiO}_{3}$. La figure 3 montre la courbe de variation de $\varepsilon_{\mathrm{r}}$ et de $\operatorname{tg} \delta$ en fonction de la température pour une céramique ferroélectrique à
5 couches série de $5 / 10 \mathrm{de} \mathrm{mm}$ d'épaisseur et de composition respective :

$$
\begin{aligned}
& \mathrm{BaTiO}_{3}-\mathrm{Ba}_{0,95} \mathrm{Sr}_{0,05} \mathrm{TiO}_{3}-\mathrm{Ba}_{0,90} \mathrm{Sr}_{0,10} \mathrm{TiO}_{3-} \\
& \mathrm{Ba}_{0,85} \mathrm{Sr}_{0,15} \mathrm{TiO}_{3}-\mathrm{Ba}_{0,80} \mathrm{Sr}_{0,20} \mathrm{TiO}_{3}
\end{aligned}
$$

Cette céramique possède une permittivité diélectrique moyenne élevée et présente des pertes faibles depuis la température ambiante jusqu'au point de Curie le plus élevé des constituants.

On peut envisager d'appliquer cette technique à d'autres compositions dont les points de Curie extrêmes sont plus éloignés.

On dispose ainsi d'un matériau de composant électronique pouvant fonctionner normalement sans changement de caractéristique, dans un large intervalle de température.

\title{
CHARACTERISTICS OF THIN, MULTI-LAYERED FERROELECTRIC CERAMICS OBTAINED BY PROJECTION WITH A PLASMA-TORCH OR BY FRITTING
}

\begin{abstract}
The authors describe the technics for getting multi-layered ferroelectric ceramics in laboratory and give some of their physical characteristics (dielectric permittivity and loss angle).
\end{abstract}

Insulating Perowskite, such as ferroelectric $\mathrm{BaTiO}_{3}$ are particulary good substances for the fabrication of miniaturised condensers or transductors if they can be obtained in thin elements. It is possible to obtain these elements either by methods involving projection with a plasma-torch, or by an appropriate fritting technique.

The study of a Barium titanate ceramic obtained by projection with a plasma-torch lead us, howewer, to two important observations :

- the dielectric constant is low at room temperature $\left(200<\varepsilon_{\mathrm{r}}<250\right)$

- the abnormal variation of dielectric constant is no longer found at the " Curie point ».

A structural analysis by X-Ray demonstrates that after projection the substance presents a pseudocubic structure at room temperature (Fig. 1). When reheated for 4 hours at $1300^{\circ} \mathrm{C}$ howewer, the structure is regenerated and it then recovers its ferroelectric properties (Fig. 2).

In view of the preceding remarks, it is relatively difficult to obtain ferroelectric ceramics by projection. So we have used the fritting technique to produce a multi-layered ferroelectric ceramic of binary compound fo the $\mathrm{Ba}_{\mathrm{x} 1} \mathrm{SrTi}_{-\mathrm{x}} \mathrm{O}_{3}$ type. Figure 3 shows the variation

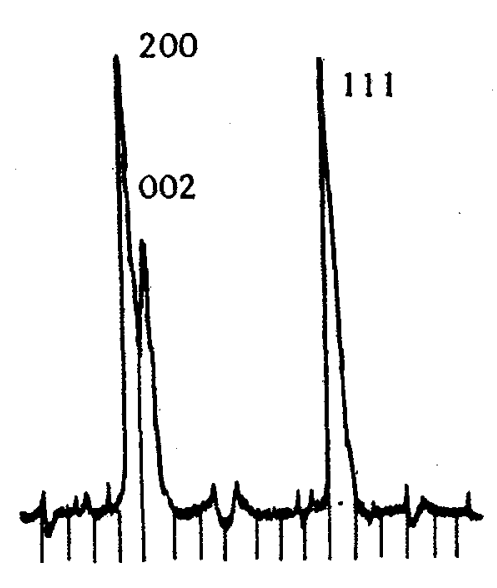

Fig. 1. - $\mathrm{BaTiO}_{3}$ after projection.

of $\varepsilon_{\mathrm{r}}$ and $\operatorname{tg} \delta$ with the temperature for a serie fivelayered ceramic $(5 / 10 \mathrm{~mm}$ depth) and respective composition :

$$
\begin{aligned}
& \mathrm{BaTiO}_{3}-\mathrm{Ba}_{0.95} \mathrm{Sr}_{0.05} \mathrm{TiO}_{3}-\mathrm{Ba}_{0.90} \mathrm{Sr}_{0.10} \mathrm{TiO}_{3^{-}} \\
& \mathrm{Ba}_{0.85} \mathrm{Sr}_{0.15} \mathrm{TiO}_{3}-\mathrm{Ba}_{0.80} \mathrm{Sr}_{0.20} \mathrm{TiO}_{3} .
\end{aligned}
$$

This ceramic has a high average dielectric permittivity in a wide range of temperature and presents weak 


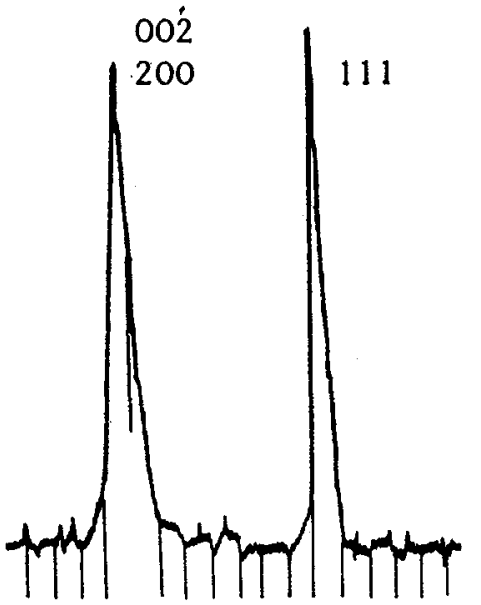

FIG. 2. $-\mathrm{BaTiO}_{3}$ after projection and thermal treatment.

losses from room temperature to the highest Curie temperature of the components.

It is possible to apply this technique to other compositions whose extreme Curie temperature are more widely spaced.

We have thus at our disposal a substance of elec-

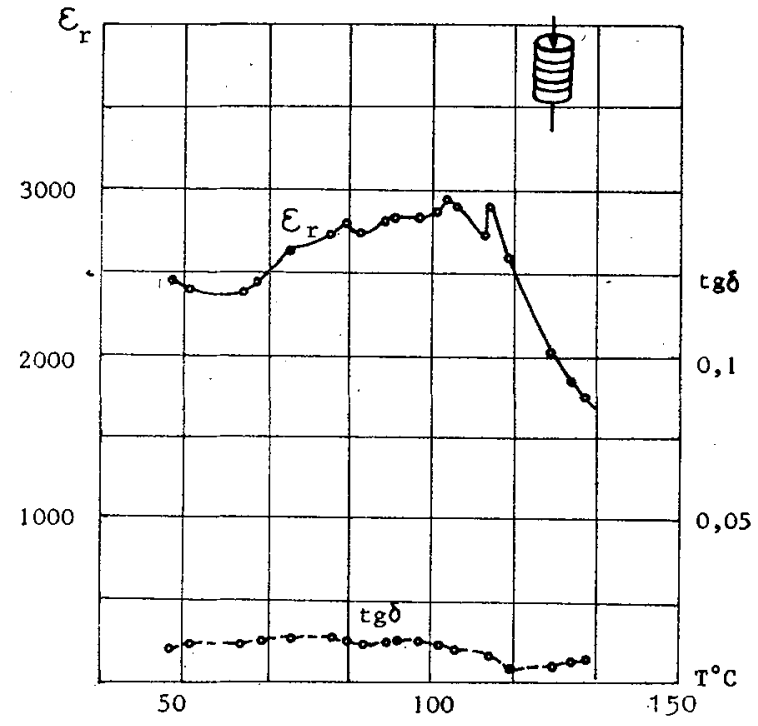

FIG. 3. - Dielectric constant and loss angle of a serie fivelayered ceramic.

tronic components capable of functioning normally within a wide range of temperature with no transformation of this characteristic.

\section{References}

Fetiveau (M.), Thèse $3^{\text {e }}$ Cycle, Lyon, 1961.

Jonker (G. H.) et SAnTen (J. H.), Rev. techn. Philips, 1949, 11, 176-185.

Delaney (R. A.) et Kaiser H. D., Proc. Elec. Comp. Conf., $1967,318-329$
Jonker (G. H.), Rev. techn. Philips, 1955, 17, 154-163.

Malcolm Mc Quarrie, J. Amer. Cer. Soc., 38, 444-449.

Coffeen (W. W.), J. Amer. Cer. Soc., 1954, 37, 480-489.

KLeimanN (H.), Thèse, Lyon, 1969. 